\title{
Pendampingan Ekowisata di Desa Kucur Kecamatan Dau Kabupaten Malang
}

\author{
Daniel Sugama Stephanus ${ }^{1}$, Rony Joyo Negoro Octavianus ${ }^{2}$ dan Sahala Manalu ${ }^{3}$ \\ ${ }^{1}$ Program Studi Akuntansi, Universitas Ma Chung, Jl. Villa Puncak Tidar N-01, Malang, Indonesia, 65151 \\ 2,3 Program Studi Manajemen, Universitas Ma Chung, Jl. Villa Puncak Tidar N-01, Malang, Indonesia, 65151
}

Correspondence: Daniel Sugama Stephanus (daniel.stephanus@machung.ac.id)

Received: 30 Juni 2021 - Revised: 01 Agustus 2021 - Accepted: 16 Agustus 2021

\begin{abstract}
Abstrak. Desa Kucur mengandalkan lahan pertanian tadah hujan atau lahan yang hanya bisa diolah pada musim penghujan. Sehingga, belum memiliki produk pertanian unggulan. Produk pertanian Desa Kucur hanyalah produk pertanian palawija seperti jagung, cabe merah, kacang tanah, tebu, cabe kecil dan ubi kayu dengan model pertanian tradisional. Komoditi sayur tidak dapat ditanam di Desa Kucur, khususnya di musim kemarau. Akibat pertanian tadah hujan tersebut banyak petani beralih pekerjaan di luar Desa, beralih ke sektor nonformal sebeagai pekerja bangunan, tukang kayu, dan pekerja serabutan. Metode hidroponik merupakan metode yang memungkinkan petani dapat bercocok tanam sepanjang tahun, karena kebutuhan air lebih sedikit dibandingkan dengan pertanian konvensional. Pendampingan ini mendorong dan mendukung usaha rintisan hidroponik dapat lebih berkembang dan menjadi unggulan desa. Lebih lanjut, usaha rintisan tersebut mampu menginisisasi pembentukan kelompok usaha masyarakat desa dan wisata yang berbasis komunitas. Kondisi ini mendorong Tim Program Pendampingan Desa Mitra (PPDM) Universitas Ma Chung, berpartisipasi mengembangkan kualitas kehidupan masyarakat Desa Kucur, khususnya lewat program Pendampingan Wisata Desa untuk peningkatan ekonomi. Kegiatan PPDM dilakukan dengan metode SLA (Sustainable Livelyhood Approach), PRA (Parsipatory Rutal Appraisal) dan CBT (Community Based Tourism). Capaian tahun ke-1 peningkatan kapasitas Sumber Daya Manusia, Tahun ke-2 Penetrasi Pasar, dan tahun ke-3 penguatan kelembagaan dan keberlanjutan usaha.
\end{abstract}

Kata kunci: Sustainable lifelihood approach, participarory rural appraisal, community based tourism, ekowisata, kewirausahaan sosial

Citation Format: Stephanus, D.S., Octavianus, R.J.N. \& Manalu, S. (2021). Pendampingan Ekowisata di Desa Kucur Kecamatan Dau Kabupaten Malang. Prosiding Seminar Nasional Abdimas Ma Chung (SENAM), 306-323 


\section{PENDAHULUAN}

\section{Analisis Situasi}

Masyarakat Desa Kucur, Kecamatan Dau, Kabupaten Malang, mayoritas bekerja sebagai buruh petani. Desa ini terdiri dari tujuh dusun, dengan total luas wilayah 158,566 Ha dengan jumlah warga 5690 jiwa (1575 KK). Adapun lahan pertanian yang digunakan, tergolong lahan tadah hujan atau lahan yang hanya biasa diolah pada musim penghujan. Sebab di luar musim penghujan, warga kesulitan mendapatkan pengairan untuk pertanian. Kebutuhan air pada musim kemarau, hanya bisa digunakan untuk memenuhi kebutuhan sehari-hari di luar kebutuhan untuk pengairan lahan pertanian.

Keterbatasan air tersebut mengakibatkan lahan tidak bisa diolah sepanjang tahun, sehingga banyak warga yang mencari pekerjaan ke luar Desa. Mayoritas mereka diserap ke dalam sektor nonformal, misalnya pekerja banggunan, tukang kayu, dan pekerja serabutan. Pada pihak lain, tingkat pendidikan warga setempat, mayoritas lulusan Sekolah Lanjutan Pertama (SLTP). Hal tersebut disebabkan, jarak terdekat Sekolah Lanjutan Tingkat Atas (SLTA), baik SMA maupun STM, sekitar $10 \mathrm{~km}$. Jarak tersebut hanya bias diakses dengan kendaraan pribadi.

Dalam Rencana Pembangunan Jangka Menengah (RPJM) Desa Kucur 2017, disebutkan jumlah KK prasejahtera 24 \%, KK sejahtera 17,9 \% KK Kaya 16,3 \%. dan KK Miskin 12,5\%. Oleh karena itulah, desa ini termasuk dalam kategori desa tertinggal. Kondisi inilah yang mendorong Tim Program Kemitraan Masyarakat Stimulus (PPDM) Universitas Ma Chung, turut berpartisipasi mengembangkan kualitas kehidupan masyarakat Desa Kucur.

\section{MASALAH}

Adapun beberapa permasalahan yang dapat diidentifikasi dan dipetakan dalam kegiatan survey awal. Permasalahan tersebut antara lain dijabarkan sebagai berikut. Desa Kucur mengalami degradasi daya dukung alam, berupa kekeringan pada musim kemarau yang berakibat pada tingkat kesuburan dan produktivitas yang rendah. Namun di Desa Kucur memiliki sumber daya mata air yang belum dikelola dengan baik, yaitu terletak di Dusun Turi, Desa Kucur. Sumber mata air tersebut secara topografi terletak di dataran yang rendah, sehingga sulit untuk diakses dan dimanfaatkan. Kondisi sosial di Desa Kucur memiliki modal sosial berupa semangat dan nilai-nilai gotong-royong yang cukup kuat, 
akan tetapi karena keterbatasan lapangan pekerjaan dan nminimnya akses pendidikan mengakibatkan arus urbanisasi juga cukup tinggi. Hal ini berakibat potensi terganggunya relasi sosial karena mobilitas yang tinggi tersebut.

Tingkat perputaran ekonomi relatif rendah karena ketergantungannya terhadap pertanian musiman. Air menjadi faktor yang sangat penting bagi kegiatan penghidupan sehari-hari di Desa Kucur seperti kegiatan peternakan, pertanian, perkebunan, dan rumah tangga. Terdapat sumber air di Desa Kucur namun tidak terkelola dengan baik. Area di sekitar sumber mata air masih membutuhkan pembangunan dan penataan tata ruang yang lebih baik, sehingga dapat dimanfaatkan keberadaanya.

\section{Solusi Permasalahan}

Setelah mencermati situasi dan permasalahan tesebut, Tim menitik-beratkan penciptaan pasar melalui wisata desa sebagai jalan keluar. Tata kelola air menjadi hal yang sangat penting, pertanian jeruk menjadi salah satu sumber daya alam yang paling banyak diusahakan oleh petani di Desa Kucur. Keberadaan sumber air dikelola untuk sebagai alternatif pendapatan bagi masyarakat serta menyediakan lapangan pekerjaan supaya menguranggi arus urbanisasi. Wisata Desa merupakan salah satu alternative solusi yang tepat untuk memanfaatkan potensi baik alam, social, manisia, keuangan, dan infrastruktur.

Wisata Desa dibangun dengan berbasiskan pengelolaan oleh komunitas dan dengan memperhatikan kaidah-kaidah konservasi lingkungan. Pengelolaan potensi desa dikelola secara partisipatorik sehingga mampu meningkatkan kapasitas warga. Diharapkan dengan adanya Wisata Desa itu mampu membuka peluang pasar baru, baik sektor pertanian, perdagangan, dan jasa. Sektor yang berpotensi dikembangkan dalam pasar tersebut adalah buah jeruk serta produk turunannya. Diharapkan sector perdagangan yang lain, seperti produk kopi, aneka keripik dari umbi-umbian sebagai produk oleh-oleh.

\section{METODE PELAKSANAAN}

Metode pelaksanaan PPDM di Desa Kucur adalah sebagai berikut.

1. Ceramah. Metode ceramah dilakukan pada tahapan awal untuk memperkenalkan Metode SLA (Sustainable Livelyhood Approach), Chambers (1991), PRA 
(Parsipatory Rutal Appraisal), Scoones, (2015), dan CBT (Community Based Tourism), The Mountain Istitute, (2000).

2. Lokalatih. Metode lokalatih merupakan pelatihan yang memberikan kerangka teori dasar, disertai praktek.

3. Latihan lapang. Metode latihan lapangan merupakan penerapan langsung kerangka teori yang telah didapatkan pada tahap sebelumnya.

\section{Tahapan Kegiatan}

Tahapan kegiatan pengabdian tahun ke-1 yang akan dilaksanankan dalam kegian PPDM ini yaitu:

1. Survey Lokasi dan Analisis Kebutuhan

2. Mengadakan FGD permasalahan dan solusi

3. Pelatihan SLA dan PRA

4. Pelatihan CBT

5. Pelatihan analisis pasar

6. Menyususun Modul Pelatihan

7. Penyusunan renstra Wisata Desa

8. Monevin Kegiatan PPDM

9. Penilaian kinerja pelaksanaan PPDM

10. Penulisan Laporan, penyusunan artikel jurnal, artikel media masa elektronik, dan pembuatan video kegiatan.

\section{HASIL DAN PEMBAHASAN}

\section{Materi tentang Pariwisata Berbasis Masyarakat}

Dasar Hukum:

1. Perpres dan Pergug tentang prioritas pariwisata unggulan nasional (TNBTS dan sekitarnya).

2. Potensi wisata pasca pandemi Covid19.

1) Cara baru berwisata.

2) Perubahan minat wisata. 
3) Cara untuk menyesuaikan dengan perubahan dan kecenderungan wisatawan.

Perencanaan:

LGS Desa Kucur memiliki banyak potensi, demikian pula dengan Desa Kucur. Tetapi, masih ada banyak kendala dan masalah yang harus hadapi dan diselesaikan. Salah satunya adalah "naik kelas" dari wisata berdasar tiket dan berdasar paket.

Pariwisata dalah bisnis, tetapi Wisata Desa lebih dari sekadar bisnis. Sehingga, perlu:

1. Rencana Bisnis (business plan).

2. Perhitungan bisnis (titik impas (BEP), waktu pengembalian (PP), nilai sekarang bersih (NPV), dan lain sebagainya.

3. Cara menjual jasa dan produk wisata berbasis potensi lokal.

4. Contoh LGS: Potensinya adalah Air, Produknya adalah Pemandian.

Pemetaan Sekilas Potensi Desa Kucur:

1. LGS sebagai Pemandian dan Bumi Perkemahan.

2. Bukit Jabal: Bumi Perkemahan.

3. Perkebunan Jeruk.

4. Perkebunan dan Pengolahan Kopi.

5. Bersih Desa.

Harus dirumuskan Visi Pariwisata sebagai cita-cita bersama. Tahapan Pengembangan Wisata Berbasis Masyarakat:

1. Menyamakan Visi (cita-cita) bersama.

2. Rencana Induk Pengembangan Pariwisata Desa (RIPDesa).

1) Investasi.

2) $3 \mathrm{~A}$ (Aksesibilitas, Amenitas, dan Atraksi)

3) Kelestarian alam dan lingkungan hidup.

3. Kelembagaan, tata kelola, dan SOP.

4. Pengelolaan (Manajemen).

1) Pengelolaan pengunjung

(1) Datang - parkir - masuk - dan seterusnya.

(2) Biaya - harga - pendapatan - pembagian keuntungan. 
(3) Zonasi kawasan.

2) Kode etik wisatawan

(1) Edukasi pengunjung.

(2) Tata krama setempat.

(3) Norma-norma sosial.

3) Sistem keuangan

(1) Sistem bagi hasil.

(2) Transparnsi dan akuntabilitas.

(3) Pengembangan SDM.

(4) Pengembangan produk (berdasar pasar atau bedasar produk).

(5) Pemasaran.

5. Kesadaran bersama,

6. Regenerasi.

1) Politik desa.

2) Kepemimpinan.

Indikator Pariwisata sebagai Bisnis:

Produk Wisata (+) Pengelolaan Pelayanan (+) Pasar Wisatawan, memerlukan:

1. Survey Pasar.

2. Potensi Pasar.

3. Menjaga potensi (SLA).

4. Pengembangan SDM.

5. Branding.

Rantai Pariwisata:

Wisatawan: menikmati dan kemidian membeli.

Produk-Produk Pariwisata:

1. Suasana dan atmosfer.

2. Jasa layanan.

3. Fasilitas.

4. Kenang-kenangan.

5. Daya tarik wisata

1) Alam.

2) Budaya.

3) Aktivitas.

4) Peristiwa (tradisional dan modern). 
Tabel 1. Tabel Produk

\begin{tabular}{|l|l|}
\hline \multicolumn{1}{|c|}{ Produk Utama } & Produk Pendukung $\rightarrow$ butuh kreativitas \\
\hline 1. Tiket. & 1. Transportasi. \\
2. Parkir. & 2. Akomodasi (homestay) \\
3. Toilet. & 3. Pemandu wisata \\
& 4. Kafetaria \\
& 5. Rental alat \\
& 6. Cindera mata \\
& 7. Tour Operator \\
\hline
\end{tabular}

Tabel 2. Strategi Pariwisata dan Produk Final

\begin{tabular}{|c|c|l|}
\hline Potensi (SLA) & Pengembangan Produk & $\leftarrow$ Pasar \\
\hline Pengembangan Lembaga $\rightarrow$ & I & \multicolumn{1}{|c|}{ I } \\
\hline & V & \multicolumn{1}{|c|}{$\begin{array}{l}\text { I } \\
\text { + Atraksi) }\end{array}$} \\
\hline Pengembangan SDM $\rightarrow$ & Uji Produk & Regulasi \\
\hline
\end{tabular}

Informasi Wisatawan:

1. Jumlah

2. Informasi pasar (potensial dan aktual)

3. Pola perjalanan

4. Motivasi dan minat

5. Harapan

Mengenal Pasar: 


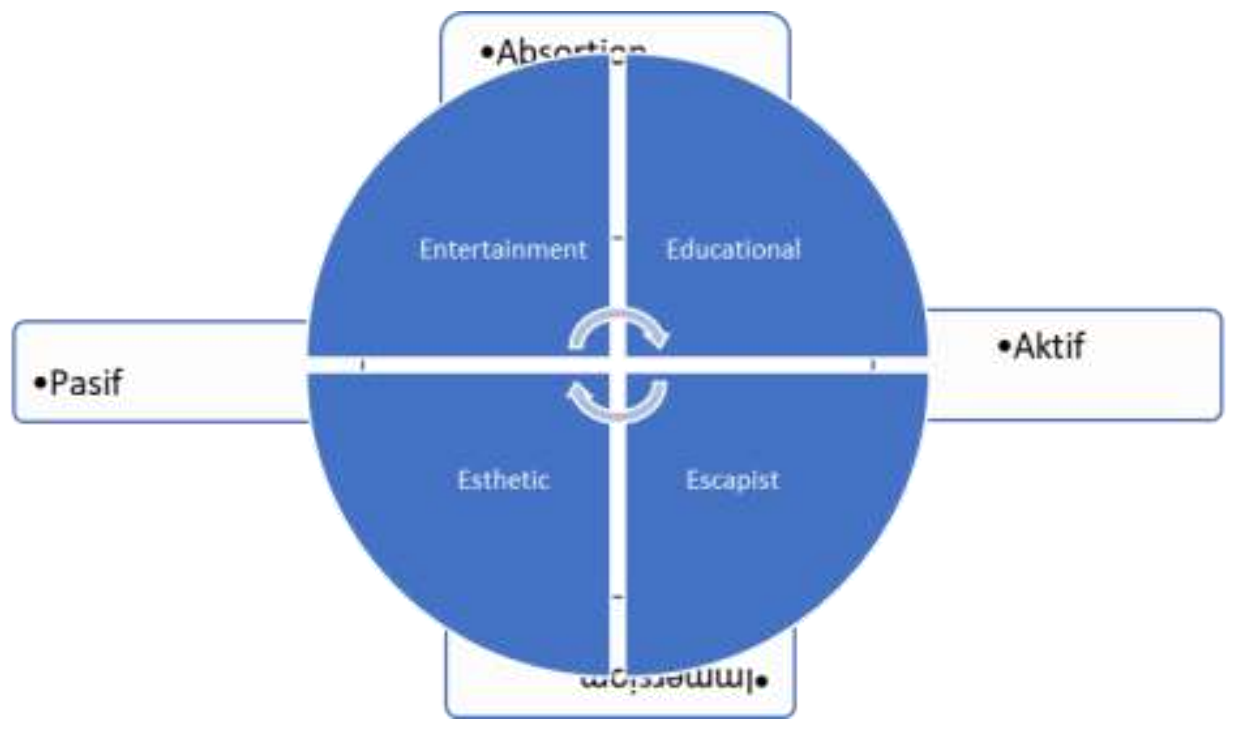

Gambar 1. Mengenal pasar

Tabel 3. Klasifikasi Wisatawan

\begin{tabular}{|l|l|}
\hline \multicolumn{1}{|c|}{ Domestic } & \multicolumn{1}{c|}{ International } \\
\hline 1. Economy & 1. Backpacker \\
2. Economy Plus & 2. Backpacker Plus \\
3. Mass Budget & 3. Masss \\
4. Family & 4. General Interest \\
5. Incentive & 5. Special Interest \\
6. Pilgrime & 6. Elite \\
\hline
\end{tabular}

Kemitraan:

Pentahelix (ABCDE): Akademisi + Birokrasi (Pemerintah) + Community

(Masyarakat) + Developmentalis (LSM dan Media Masa) + Enterprise (Dunia Usaha dan Dunia Industri).

Tabel 4. Pengembangan Berkelanjutan

\begin{tabular}{|l|l|l|}
\hline \multicolumn{1}{|c|}{$3 \mathrm{~A}$} & \multicolumn{1}{|c|}{ BOM } & \multicolumn{1}{|c|}{ BAS } \\
\hline 1. Aksesibilitas & 1. Bisnis & 1. Branding \\
2. Amenitas & 2. Organisasi & 2. Advertising \\
3. Atraksi & 3. Masyarakat & 3. Selling \\
\hline
\end{tabular}


Arah Pariwisata:

1. Pengembangan berkelanjutan.

2. Nilai (value) nilai jumlah (nominal).

3. Gaya hidup hijau.

\section{Konsepsi Ekowisata}

Ekowisata adalah pariwisata bertanggung jawab dengan prinsip Tripple Bottom Line + interpertasi. Konsep Ekowisata: Wisata Ekologis: Tripple Bottom Line + Pemberdayaan Masyarakat + Pendidikan (Dakwah).

Dampak negatif pariwisata:

1. Konservasi lahan tidak terjaga dengan baik.

2. Eksploitasi berlebihan.

3. Sampah.

4. Ganggungan terhadap satwa liar.

5. Masyarakat lokal terpinggirkan.

6. Gangguan terhadap budaya setempat.

7. Butuh:

1) Regulasi.

2) Kode etik wisatawan.

3) Kode Etik Pengelola.

Paradigma pariwisata pasca pandemi.

1. Cleanliness.

2. Higiene.

3. Safety.

Strategi:

1. Berbasis sumberdaya alam (SLA).

2. Berbasis pasar.

3. Kombinasi. 
Atribut penting:

1. Atraksi utama.

2. Atraksi pendamping.

Prinsip-prinsip pengembangan produk:

1. Lama masa Tinggal

1) Dilihat.

2) Dilakukan.

3) Dibeli.

Semakin lama tinggal, semakin banyak yang dibeli.

2. Apa yang dilakukan

1) Safety.

2) Service.

3) Story

Sapta Pesona Pariwisata Indonesia.

3. Apa yang dibeli

1) Produk

2) Proses (alur cerita).

3) Filosofi (interpertasi).

Tantangan:

1. Globalisasi dan pasar bebas.

2. Perubahan iklim.

3. Permenugan standar.

4. Paska sukses.

1) Orientasi pariwisata berubah dengan lebih mementingkan aspek ekonomi.

2) Berkurangnya komitmen regenerasi.

Fasilitas yang diperlukan:

1. Peta potensi wisata desa.

2. Aturan dan kode etik.

3. Pelatihan pemandu.

1) Skills 

(1) Persiapan.
(2) Teknik.
(3) Laporan.
(4) Komunikasi.
(5) P3K.

2) Knowledge

(1) Obyek alam.

(2) Obyek buatan.

(3) Istilah.

(4) Manajemen dan kepemimpina.

3) Attitude

4. Peningkatan kapasitas pengelola.

Menilai atau mengukur kondisi aktual $(1-10)$ :

1. Sarana dan Prasarana.

2. Pelayanan informasi.

3. Pelayanan pemandu.

4. Fasilitas toilet.

5. Fasilitas homestay.

6. Fasilitas kafetaria.

7. Jaringan listrik dan komunikasi.

8. Organisasi pengelola (SOP dan Job Discription).

9. Regulasi desa.

10. Pengelolaan pengunjung.

11. Promosi.

12. Paket kegiatan.

13. Pelestarian budaya.

14. Pelestarian alam.

15. Hubungan baik dengan tetangga desa.

Jadi, membangun pariwisata desa adalah membangun masyarakat dan desa. 


\section{Sinau Bareng Wisata Desa di Desa Kucur di Taman Wisata Lembah Gunung Sari}

Tabel 5. Kegiatan sinau bareng

\begin{tabular}{|c|c|c|}
\hline Tujuan & Wisata Desa & Wisata Biasa \\
\hline Basis & Berbasis Masyarakat & Berbasis Investor \\
\hline Tujuan & $\begin{array}{l}\text { Memberdayakan Masyarakat, } \\
\text { Melestarikan Lingkungan, } \\
\text { Meningkatkan Pendapatan } \\
\text { Desa }\end{array}$ & $\begin{array}{l}\text { Mendapatkan keuntungan } \\
\text { sebanyak-banyaknya untuk } \\
\text { pengembalian investasi. }\end{array}$ \\
\hline Pengelola & BUMDesa & Investor \\
\hline Hasil & $\begin{array}{lr}\text { Pemberdayaan } & \text { dan } \\
\text { Konservasi, Profit hanya } \\
\text { hasil akhir. }\end{array}$ & $\begin{array}{lr}\text { Eksploitasi } & \text { untuk } \\
\text { memperoleh keuntungan } \\
\text { sebesar-besarnya. }\end{array}$ \\
\hline & & \\
\hline
\end{tabular}

\section{Rencana Induk Pengambangan Pariwisata}

1. Potensi Desa

2. Rencana Pembangunan Jangka Menengah Desa

3. Peraturan Desa

4. Badan Usaha Milik Desa

5. Unit Usaha BUMdesa

Desa Kucur: 6 Unit Usaha BUMDesa. Salah satunya adalah Wisata Lembah Gunung Sari (LGS).

Potensi (WIsata Desa) Kucur: (1) LGS, (2) Pendakian dan Perkemahan Jabal, (3) Wisata Jeruk, (4) Sekolah Kopi Kucur, (5) Jelajah Kampung, (6) Trekking dan Gowes, (7) Budaya, Seni, dan Adat Istiadat, (8) UMKM, (9) Upacara Desa (Bersih Desa \& Bersih Dusun), (10) Edukasi Pengelolaan Pakan Ternak, dan lain sebagainya.

\section{Kebutuhan}

1. Pemetaan potensi dan aset wisata Desa.

2. Penyusunan Rencana Strategis Wisata Desa beberasis RPJMDesa.

3. Penyusunan Rencana Operasi Wisata Desa berbasis Rencana Anggaran Pembangunan dan Alokasi Dana Desa. 
4. Restrukturisasi Organisasi BUMDesa Kucur dan Penyusunan Sistem Pembagian Kerja serta Kontribusi masing-masing Unit Usaha pada APBDesa.

5. Pola Perekrutan dan Pelatihan peningkatan kapasitas SDM untuk Pengelola BUMDesa dan Unit-Unit Usaha.

6. Dibentuk TIm Kerja atau Gugus Tugas Pengembangan BUMDesa dan Unit Usaha Wisata LGS.

\section{Rencana Tindak Lanjut}

1. Pertemuan dengan Kepala Desa Kucur untuk mengusulkan Reorganisasi BUMDesa dan Unit Usaha Wisata LGS. Direncanakan pada Rabu, 02 September 2020.

2. Menghadiri Sarasehan dan Jalin Aspirasi untuk Restrukturusasau dan Optimalisasi BUMDesa serta Unit-Unit Usaha antara Kepala Desa, Pemdes, BPD, dan Tokoh Masyarakat. Tentatif: ijin dari Kepala Desa.

3. Pendampingan TIm Kerja atau Gugus Tugas Perekrutan SDM untuk BUMDesa dan Unit Usaha Wisata LGS.

\section{Mediasi dengan Kepala Desa Kucur untuk Reorganisasi BUMDesa dan Unit Usaha Wisata LGS}

\section{Latar Belakang}

Kepengurusan BUMDesa belum lengkap karena ketiadaan Sekretaris. Sudah ada calon tetapi saat ini masih menjadi Anggota BPD sehingga tidak bisa diangkat secara resmi, walau beliau sudah terlibat aktif di Unit Usaha LGS sebagai Penanggung Jawab Tiket dan Persewaan Ban. mBak WIwin akan diusulkan untuk mundur dari Anggota BPD dan akan fokus untuk menjadi Pengurus BUMDesa dan Unit Usaha Wisata LGS.

Rencana Pengembangan Unit Usaha Wisata Kebun Jeruk dengan memanfaatkan Tanah Kas Desa. Tanah Kas Desa sebagai bagian dari APBDesa ditujukan untuk memberi kontribusi pada PADesa. Akan dikelolakan pada BUMDesa untuk memberi kontribusi positif pada PADesa dan APBDesa. Selama ini, desa masih harus melakukan subsidi APBDesa dari Tanah Kas Desa yang belum memberikan hasil yang optimal. Kondisi ini bukan hanya mendapat restu tetapi sesuai dengan petunjuk Camat Dau. 
Pendakian dan Perkemahan Jabal yang saat ini telah dikelola oleh Karang Taruna Dusun Sumber Bendo dan Karang Taruna Desa. Disiapkan Dana Desa untuk mendukung operasional PP Jabal sebesar Rp30 juta untuk pembangunan fasilitas saliran air dan MCK di tanah Desa atau Masyarakat. Pengelola saat ini terdiri dari Anggota Karang Taruna Dusun Sumber Bendo dan Relawan. Dipersiapkan sebagai pengembangan Unit Usaha tersendiri dari BUMDesa. Saat ini Desa hanya mendapat Retribusi Rp1.000 perorang dari tiket masuk. Sedangkan Parkir menjadi pendapatan bagi pemilik lahan dan Karang Taruna Sumber Bendo. Pendamping Pak Misdianto Sumber Bendo, mantan Sekretaris Desa dan Staf dan Fasilitator di Pusat Penyelamatan Satwa Petung Sewu dan Javan Langur Center di Junggo Kota Batu.

Pola perekrutan SDM untuk Pengelola Unit Usaha di BUMDesa telah sesuai dengan kaidah dan prosedur yang baik. Pertama, membuka lamaran untuk umum. Kedua, bila tidak ada pelamar akan dilakukan proses penunjukkan langsung. Pola yang sama sebenarnya telah dilakukan pula untuk perekrutan Pamong untuk Pemerintahan Desa.

Pendekatan Metafisis, bahwa Kepada Desa telah mendapat restu dari Penguasa LGS melalui Sang Naga Penunggu Sumber Lanang (sumber mata air di sebelah barat).

Wisata LGS belum diresmikan dan dibuka secara resmi karena Kelembagaan, Pengelolaan, dan Tata Kelola belum tertata dengan baik. Tetapi, tetap dibuka untuk umum dan telah beroperasi serta terpublikasi. Kesepakatan dengan SDM Wisata LGS: (1) Tiket Rp50.000 perhari, (2) Upah Pekerja Rp600.000 perbulan, (3) Sistem Bagi Hasil penjualan Makanan dan Minuman, modal dari BUMDesa.

Unit Usaha Air relatif berjalan dengan baik dan terkelola dengan baik pula. Bahkan telah memiliki Rekening terpisah di BRI. Sedangkan Unit Usaha Wisata LGS masih butuh penataan dan peningkatan kapasitas kelembagaan dan SDM, bahkan Rekening Bank masih menjadi satu dengan Rekening BUMDesa.

Masukan dan Peringatan dari Camat Dau untuk melakukan reorganisasi dan restrukturisasi BUMDesa, karena masih masuknya Perangkat Desa pada Pengelola Unit Usaha BUMDesa. Walau ketiadaan SDM, tetapi bukan menjadi alasan pembenar karena bertentangan dengan hukum dan peraturan serta perundang-undangan yang berlaku. 
Seharsusnya Kepala Desa dan Pemerintah Desa selaku inverstor dan pemengang saham mayoritas adalah Komisaris dari BUMDesa. Pengurus BUMDesa adalah Dewan Direksi BUMDesa. Kepata Unit Usaha adalah Manajer-Manajer Bisnis dan Operasional.

\section{Analisis Kebutuhan}

1. Penguatan Kapasitas Kelembagaan, Tata Kelola, dan SDM untuk BUMDesa dan Unit Usaha Wisata LGS.

2. Rencana Induk Pengembangan Wisata Desa dengan LGS sebagai Proyek Percontohan dan Laboratorium Penguatan Kapasitas Kelembagaan dan SDM.

a) Pemetaan Potensi dan Modal Wisata Desa

b) Pemetaan dan penataan kawasan Wisata Desa

i. Panggung Budaya

ii. Warung dan Kafetaria

iii. Pasar minggu

iv. Bumi perkemahan dan outbound

V. Festival desa

vi. Ruang kerja bersama

c) Peta dan Perencanaan Perjalanan Jelanjah Kampung (gowes dan jalan-jalan di desa)

3. Penguatan Kapasitas SDM untuk pengelolaan Anggaran Pendapatan dan Pembelajaan Dana Desa serta Kontinisi pada APBDesa dari Penyertaan di BUMDesa.

4. Penguatan Kapasitas SDM untuk Pelaporan dan Laporan Keuangan BUMDesa, Kontibusi pada APBDesa, dan Sistem Keuangan Desa yang terintegrasi dan terlaporkan dengan baik (transparan, akuntabel, dan tata kelola baik).

5. Penguatan kapasitas kelembagaan dan SDM untuk pengelolaan dan tata kelola PP Jabal.

6. Pembentukan Tim Kerja atau Gugus Tugas Percepatan BUMDesa:
a) Perekrutan SDM

b) Pelatihan dam penguatan kapasitas SDM

c) Menyusun Rencana Strategis, Rencana Operasional, Program Kerja, dan Tata Kelola BUMDesa dan Unit-Unit Usaha berbasis RPJMDesa dan APBDesa.

7. Reorganisasi dan restrukturisasai kelembagaan dan tata kelola Unit Usaha Wisata LGS sebagai Proyek Percontohan Tata Kekola Baik dan Laboratorium penguatan kapasitas Kelembagaan dan SDM untuk Unit Usaha BUMDesa lainnya. 
8. Pengembangan dan penguatan kapasitas kelembagaan dan SDM Unit Usaha Sampah, Air, dan Listrik melalui aplikasi (digitalisasi).

\section{Rencana Tindak Lanjut}

1. Sarasehan untuk restrukturisasi dan reorganisai BUMDesa dan Unit-Unit Usahanya akan dilaksanakan oleh Kepala Desa dan Perangangkat Desa sendiri.

Pak Karim selaku Kepala Desa Kucur akan didundang pada Hari Kamis, 17 September 2020 untuk menyampaikan RPJM Desa dan Kebutuhan Pendampingan oleh Universitas Ma Chung.

\section{PENUTUP}

\section{Kendala}

1. Kelembagaan di LGS belum tersusun rapi. Sebagai bagian dari Badan Usaha Miliki Desa (BUMDes) bagus secara tujuan, visi, dan misinya tetapi lemah pada sisi tata kelola. Belum ada Pengelola tetap dan masih bersifat keralanan.

2. Ketiadaan Sumber Daya yang bisa dijadikan pengelola LGS menyulitkan LGS terkelola secara professional apalagi bila harus memperhatikan aspek Wisata BertanggungJawab sebagai syarat dari Ekowisata.

3. LGS belum terintegrasi dengan Rencana Induk Pembangunan Pariwisata Desa sehingga di Desa Kucur Potensi Wisata dikelola di masing-masing Dusun dan belum terkelola sebagai Wisata Desa.

\section{Simpulan}

1. LGS dapat berjalan dan beroperasional dengan lancar tetapi belum terkelola secara professional dan masih bersifat kerelawanan saja. Sehingga, prinsip pariwisata yang bertanggung jawab (responsible tourismI) apalagi prinsip ekowisata berkelanjutan, sedangkan tata kelola yang baik sebagai tempat wisata saja belum bisa dilakukan. Hal ini dikarenakan ketiadaan SDM yang berkenan bekerja secara professional dan waktu penuh untuk mengelola LGS seabagai kawasan Wisata Desa yang berpotensi besar.

2. LGS sebagai bagian dari BUMDes seharusnya dapat memberi kontribusi yang cukup signifikan pada Pendapatan Asli Daerah (PAD) Desa Kucur. Walau tujuan, visi, \& 
misi investasi LGS sebagai bagian dari menyejahterahkan rakyat dapat dicapai dan juga bagian dari penyelamatan dan pemeliharaan maya air, aspek kontribusi pada peingkatan pendapatan masyarakat dan desa seharusnya juga mendapat perhatian.

3. LGS belum terintegrasi dengan potensi dan wisata lain yang ada di Desa Kucur sebagai bagian dari Rencana Induk Pembangunan Pariwisata Desa di Desa Kucur.

\section{Rencana Tindak Lanjut}

1. Peningkatan Kapasitas SDM sebagai pengelola tempat wisata yang professional sembari memperkenalkan konsep Wisata yang Bertanggung Jawab dan Ekowisata.

2. Penguatan Kapasitas Kelembagaan untuk membagun lembaga Wisata Desa yang baik dan bertata kelola baik dengan berprinsip pada Ekowisata.

3. Mengintergrasikan rencana pembanganan pariwisata di Desa Kucur sebagai sebuah Rencana Induk Pembangunan Pariwisata Desa.

4. Tata kelola dan kelembagaan Badan Usaha Milik Desa (BUMDes) Desa Kucur yang mapan.

5. Kontribusi BUMDes pada Pendapatan Asli Desa (PAD) Desa Kucur.

\section{UCAPAN TERIMA KASIH}

Terima kasih kami sampaikan kepada semua pihak yang telah membantu kelancaran pelaksanaan Pendabdian Ekowisata di Desa Kucur. Khususnya kepada Perangkat Desa Kucur, Pengurus Badan Usaha Milik Desa Kucut, Pengelola Wisata Alam Lembah Gunung Sari, Pengurus East Java Ecotourism Forum (EJEF), dan Dosen dan Staf Fakultas Ekonomi Universitas Ma Chung, dan Kepala dan Staf Lembaga Penelitian dan Pengabdian Kepada Masyarakat yang membantu kelancaran pelaksanaan Program Pengabdian masyarakat ini. 


\section{DAFTAR PUSTAKA}

Chambers, R. \& Conway, G.R.. (1991). Sustainable Rural Livelihoods: Practical Concepts for the 21st Century. University of Sussex: Institute of Development Studies.

Konsorsium Hijau. (2016) Panduan Participatory Assessment. Yogyakarta: Tim Konsorsium Hijau.

Peraturan Menteri Pariwisata dan Ekonomi Kreatit No. 4 tahun 2021 tentang Standar Kegiatan Usaha Pada Penyelenggaraan Perizinan Berusaha Berbasis Risiko Sektor Pariwisata.

Widiadi, P \& Stephanus, D.S. (2019). Buku Panduan Pembangun Desa Hijau Berbasis Pendekatan Pembangunan Lestari. Indonesia: World Wide Fund Indonesia.

Scoones, I. (2015). Sustainable Rural Livelihoods and Rural Development. UK: Practical Action Publishing and Winnipeg, CA. Fernwood Publishing.

The Mountain Istitute. (2000). Community Based Tourism For Conservation And Development A Resources. Washington D.C: The Mountain Istitute

(C) 2021 by authors. Content on this article is licensed under a Creative Commons Attribution 4.0 International license. (http://creativecommons.org/licenses/by/4.0/). 